Forum

\title{
Framework for Comparing Ecosystem Impacts of Developing Unconventional Energy Resources on Western US Rangelands
}

\author{
Urs P. Kreuter, ${ }^{1}$ William E. Fox, ${ }^{2}$ John A. Tanaka, ${ }^{3}$ Kristie A. Maczko, ${ }^{4}$ Daniel W. McCollum, ${ }^{5}$ \\ John E. Mitchell, ${ }^{6}$ Clifford S. Duke, ${ }^{7}$ and Lori Hidinger ${ }^{8}$
}

Authors are ${ }^{1}$ Professor, Department of Ecosystem Science and Management, Texas A\&M University, College Station, TX 77843, USA; ${ }^{2}$ Assistant Professor, Texas AgriLife Research, Blackland Research \& Extension Center, Temple, TX 76502, USA; ${ }^{3}$ Professor and Department Head and ${ }^{4}$ Research Scientist, Renewable Resources, University of Wyoming, Laramie, WY 82071, USA; ${ }^{5}$ Research Scientist and ${ }^{6}$ Emeritus Scientist, Rocky Mountain Research Station, Fort Collins, CO 80526, USA; ${ }^{7}$ Director of Science Programs, Ecological Society of America, Washington, DC 20036, USA; and

${ }^{8}$ Managing Director, Consortium for Science, Policy and Outcomes, Arizona State University, Tempe, AZ 85287, USA.

\begin{abstract}
More diverse sources of energy are needed for countries to progress toward energy independence and to meet future food production needs. The US Task Force on Strategic Unconventional Fuels concluded that to achieve this objective it is essential to develop a domestic unconventional fuels industry. Rangelands, which cover $50 \%$ to $70 \%$ of the earth's terrestrial surface and dominate much of the western half of the United States, represent a major source of alternative energy resources. A framework to systematically identify biophysical-socioeconomic links that influence the delivery of ecosystem services affected by alternative uses of rangelands has been lacking. The Integrated Social, Economic, and Ecological Conceptual framework was developed by the Sustainable Rangeland Roundtable to address this deficiency. We apply this framework to demonstrate how the effect on ecosystem services of exploiting rangeland-based biofuel, natural gas, and wind energy resources can be systematically compared. We also demonstrate the use of this framework for selecting suitable indicators to monitor changes in the biophysical-socioeconomic links affected by the development of these unconventional energy sources. This type of approach can potentially enhance coordination between federal, state, and local agencies that are attempting to set polices and regulations for the sustainable development of unconventional energy resources on rangelands.
\end{abstract}

\section{Resumen}

Más diversidad de fuentes de energía es necesaria para que los países progresen hacia la independencia energética y cumplan con sus necesidades futuras de alimentación. El grupo estratégico para combustibles no-convencionales de los EUA concluyó que para lograr el éste objetivo, es esencial desarrollar una industria de combustibles no-convencionales interna. Los pastizales, quienes cubren entre el 50 al $70 \%$ de la superficie del planeta y dominan más de la mitad del oeste de EUA representan la mayor fuente de recursos de energía alternativa. Hace falta desarrollar un marco conceptual que sistemáticamente identifique los enlaces biofísicos-socioeconómicos que influyen en la entrega de los servicios de los ecosistemas que son afectados por los usos alternativos de los pastizales. El Marco Conceptual de Integración Social, Económica y Ecológica desarrollado por la Mesa de Sostenibilidad de los Pastizales está dirigido para atender esta deficiencia. Aplicamos este marco conceptual para demostrar como el efecto en los servicios del ecosistema por la explotación de biocombustibles basados en los pastizales, gas natural y fuentes de energía eólica pueden ser comparados sistemáticamente. También demostramos que el uso de este marco conceptual para seleccionar indicadores adecuados para monitorear cambios en los enlaces biofísicos-socioeconómicos afectados por el desarrollo de estas fuentes de energía no convencionales. Este tipo de punto de vista puede potencialmente enriquecer la coordinación entre las agencias federales, estatales y locales que están intentando establecer políticas y regulaciones en el desarrollo sostenible de fuentes de energía no convencional en pastizales.

Key Words: alternative, biophysical, ecosystem services, fuel, indicators, socioeconomic

\section{INTRODUCTION}

Energy is fundamental to sustainable development because it provides the means for resolving challenges facing humanity, including water and food shortages and poverty (Serageldin 1999; Kalogirou 2005). For the most part, 20th century agriculture was characterized by abundant, low-cost energy derived from fossil fuels, which accounted for $90 \%$ of global

\footnotetext{
Correspondence: Urs P. Kreuter, Professor, Dept of Ecosystem Science and Management, Texas A\&M University, College Station, TX 77843, USA. Email: urs@tamu.edu
}

Manuscript received 21 October 2011; manuscript accepted 26 February 2012. primary energy consumption by the end of the century with about $40 \%$ being derived from crude oil (Smil 2000). The remaining $10 \%$ of energy demand was met almost exclusively by hydroelectric and nuclear power, while renewable energy (solar, wind, geothermal) provided less than 1\% (Duncan 2001). Similarly, $91 \%$ of net electricity production in the United States in 2005 was derived from nonrenewable resources and much less from renewable resources (hydro $6.5 \%$, biomass $1.5 \%$, wind $0.44 \%$, geothermal $0.36 \%$, and solar $0.01 \%$; Black and Veatch 2008).

To reduce the dependence on declining nonrenewable fossil fuel reserves, there is broad agreement that more diverse sources of energy are needed for developed countries (Resourc- 
es for the Future 2005). Specifically, Section 369(i) of the US Energy Policy Act of 2005 directed the US Department of Energy (USDOE) to develop an Unconventional Strategic Fuels Program. In response, the Secretary of Energy convened a Task Force on Strategic Unconventional Fuels, which concluded: "Increasing global oil demand, declining reserve additions, and our increasing reliance on oil and product imports from unstable foreign sources require the Nation to take immediate action to catalyze a domestic unconventional fuels industry" (USDOE 2010).

In North America, many untapped renewable energy resources are associated with rangelands. These represent diverse ecosystems and landforms that are unsuited for intensive agriculture or forestry because of climatic, edaphic, and/or topographic limitations (Stoddart et al. 1975; Society for Range Management 1998; Holechek et al. 2004). Such ecosystems comprise about $50 \%$ to $70 \%$ of the earth's landmass, depending on the extent to which woodlands and arid areas are included (World Resources Institute 1986; Mitchell 2000; Holechek et al. 2004). In the United States, rangelands cover over 300 million ha or one-third of the country (Joyce 1989; Mitchell 2000; Havstad et al. 2007) mainly west of the 95th meridian. Due to their vastness, rangelands hold substantial potential for development of renewable energy resources while also providing critical ecosystem services.

Ecosystem services are broadly defined as "the benefits people obtain from ecosystems" (Millennium Ecosystem Assessment 2005, p. V) and more specifically as "the components of nature, directly enjoyed, consumed, or used to yield human well-being” (Boyd and Banzhaf 2006, p. 8). These services are derived from natural biophysical processes that are fundamental to properly functioning, healthy, and resilient ecosystems (Daily et al. 1997). However, many ecosystem services are deteriorating because of the externalization of longterm environmental costs associated with human exploitation of extractable natural resources (goods) provided by ecosystems at the expense of the services that they deliver (Lant et al. 2008). This is clearly not a sustainable strategy for the future well-being of rangeland-based social-ecological systems.

The recommendation to develop unconventional domestic fuels has ramifications for the continued delivery of ecosystem services from rangelands because exploiting untapped energy sources can directly and indirectly affect the biophysical attributes, integrity, and resilience of these ecosystems. Evaluating the nature and magnitude of such impacts is, however, hindered by the complex and multiscale interactions between biophysical and socioeconomic factors that affect the functionality of ecosystems. Due to these complexities, such interactions are frequently discounted or ignored (Nicholson et al. 2009), but understanding them is critical for ensuring the maintenance of ecosystem resilience. Ostrom (2009) pointed out that understanding processes that affect natural resources is hindered by the inconsistent use of concepts and terms by diverse scientific disciplines to describe complex social-ecological systems. This is especially problematic when the development of management solutions to deal with ecosystem degradation requires engagement by diverse stakeholders with varying degrees of scientific sophistication and comprehension of underlying drivers of ecosystem dynamics.
To illustrate the interaction between system complexity and integrated solutions in the context of a renewable energy resource, we refer to Gasparatos et al. (2011). They stated that, while biofuels can enhance some ecosystem services, they compromise others, but such knowledge is fragmented. They developed a conceptual framework to illustrate trade-offs in the production and use of biofuels by using consistent language grounded on the concepts of ecosystem services. They concluded, however, that there are significant research needs before such ecosystem service-based frameworks can be used effectively. Specifically, they identified knowledge gaps about: 1) the impact of biofuel production and use on ecosystem services and the links between affected ecosystem services and human wellbeing; 2) valuation of such ecosystem services; and 3) policy implications. They conclude that a robust framework combining these elements in a meaningful manner has not yet been developed.

To address this sort of challenge, the Sustainable Rangeland Roundtable (SRR) developed the Integrated Social, Economic, and Ecological Conceptual (ISEEC) framework. This framework provides a useful tool to disentangle the complexity of the provision of ecosystem services and impacts of alterative rangeland uses on the ecosystems that provide them (Fox et al. 2009). ISEEC does this by facilitating the systematic identification of interactions between key biophysical and socioeconomic factors that influence the integrity of ecosystems and by aiding in the selection of appropriate indicators to monitor such interactions over time (Fox et al. 2009).

In this paper, we demonstrate how the ISEEC framework can be used in the context of unconventional energy development on rangelands to identify the social-ecological links that influence delivery of ecosystem services on rangelands, and then to describe how this information can be used to determine appropriate indicators for monitoring these links over time. First, we summarize the potential of western rangelands for future production of three energy resources: natural gas, biofuel, and wind energy. Next, we describe the ISEEC framework and how it can be used to identify biophysicalsocioeconomic links that affect the delivery of ecosystem services and that may be affected by the development of biofuels. Then we show conceptually how the ISEEC framework could be applied to compare the relative effects of developing the three unconventional energy sources. Finally, we identify suitable indicators for monitoring the effects of developing the three energy sources.

\section{ENERGY PRODUCTION ON RANGELANDS IN THE WESTERN UNITED STATES}

Rangelands in the western United States hold significant potential for developing domestic fuels because a substantial amount of the nation's unconventional oil and gas reserves and renewable biofuel, wind, solar, hydropower, and geothermal energy sources are located on them (Black and Veatch 2008). We focus on three broadly distributed unconventional energy sources: renewable biofuel, shale-based natural gas, and wind energy for three reasons. Each represents a "dual-use" energy resource, i.e., one that does not preclude the simultaneous use of rangeland for traditional purposes (Pimentel et al. 1994). 
These energy sources are vertically distributed below, at, and above ground level; therefore, the development of each will likely affect rangeland ecosystems in fundamentally different ways. The exploitation of each energy resource relies on wellestablished technologies; therefore, they are more likely to be developed in the near future.

\section{Biofuels}

The USDOE's "Billion Ton Study" classified $26 \%$ of the United States to be grassland, pasture, or range, but it did not evaluate their biofuel potentials (USDOE 2005). Switchgrass (Panicum virgatum $L_{\text {.) }}$ has attracted considerable attention for energy production due to its substantial potential for producing biomass in areas where the productive capacity for other biofuel crops, such as maize, is low (Walsh et al. 2003; Adler et al. 2007; Mitchell et al. 2008). However, there are concerns over converting large swaths of native rangelands to biofuel monocultures, including increased agrichemical pollution and loss of biodiversity (Cook et al. 1991; Bies 2006; Fargione et al. 2008, 2009; Groom et al. 2008). Tilman et al. (2006) reported that, in contrast to monoculture biofuel production approaches, low-input high-diversity mixed native grasslands can produce more usable energy and greenhouse gas reductions and result in less agrichemical pollution and biodiversity in agriculturally marginal rangeland areas; in tall grass prairies, annual net primary production can exceed 10 tons $\cdot \mathrm{ha}^{-1}$ (Kucera et al. 1967).

To identify areas with quality renewable energy resources and to aid in environmentally sensitive development of such resources and associated transmission networks, the National Renewable Energy Laboratory and Western Governors' Association undertook the Western Renewable Energy Zones (WREZs) initiative (Black and Veatch 2009; Western Governors' Association 2009). Not all plant biomass on rangelands can be used for biofuel because some is required to feed herbivores and to protect soils; the WREZs analysis assumed one-third of available biomass could be used for power generation without significantly impacting livestock and wildlife production. Based on this, potential for rangelandbased biofuel production was identified in several western states including Montana, Idaho, Utah, Colorado, Arizona, New Mexico, and Texas.

\section{Natural Gas}

Since the 1970s, known global natural gas reserves have increased about $5 \%$ per year (Economides and Wood 2009). In the United States, rich shale formations (plays) that contain hydrocarbon gasses are widely distributed and contain an estimated 1744 trillion cubic feet of technically recoverable reserves (USDOE 2006; Kuuskraa et al. 2007).

Natural gas currently provides about $22 \%$ of the nation's energy supply. It is estimated that with current technology and extraction rates recoverable resources could supply natural gas for about $90 \mathrm{yr}$, while with technological developments the extraction of this resource could be extended well beyond that time period (Groundwater Protection Council [GWPAC] and ALL Consulting 2009). However, full development of the natural gas reserves will hinge on the energy industry's ability to maintain a balance between exploration/production pro- cesses and compliance with regulatory statutes and environmental directives administered by a range of federal and state agencies (GWPAC and ALL Consulting 2009). Evolving practices facilitating such balance include horizontal drilling, hydraulic fracturing, reduced water demand, and air quality improvement practices. Tied to these are efforts to reduce the surface disturbance of siting wells, reduce wildlife and community impacts, and protect groundwater resources and other site processes that reduce potential surface impacts. Developing and utilizing tools that facilitate examination of links between biophysical and socioeconomic processes that influence the delivery of ecosystem services affected by natural gas development will provide a useful foundation for assessing the local, regional, and national implications of unconventional natural gas development on rangelands. Currently identified shale gas plays in the rangelands of the western United States extend southwards from Montana through Wyoming, Utah, Colorado, and New Mexico to Texas.

\section{Wind energy}

Globally, wind-powered electricity generation has increased $25 \%$ to $35 \%$ per year during the past decade growing to about $60000 \mathrm{MW}$ globally in 2006, with about $17000 \mathrm{MW}$ being produced in the United States. Despite this growth, wind energy accounted for less than $1 \%$ of total electricity generation in 2007 (National Research Council [NRC] 2007). In addition to estimating biofuel potential, the WREZs identified areas with high wind energy potential in the western United States (Black and Veatch 2009).

The advantages of wind-energy facilities are that they are driven by a persistent energy source and emit no direct pollutants. However, developing wind-energy facilities can lead to wildlife habitat degradation and collision-related fatalities of bats and birds, especially raptors that soar along ridges where wind turbines are frequently placed (Kunz et al. 2007; Black and Veatch 2009; Curry 2009). Other effects include diminished aesthetic quality of the landscape, and elevated noise, shadow flicker, and electromagnetic interference (Krohn and Damborg 1999). Developing wind energy and building transmission lines to connect wind farms to the national electricity grid will benefit society at large. While the environmental impacts of such developments can be spatially disbursed, the environmental and social costs of such developments could be disproportionately borne by communities located near wind turbines (Denholm 2006). Accordingly, the NRC's Committee on Environmental Impacts of Wind-Energy Projects provided a framework for evaluating the benefits and risks of wind-energy projects and recommended that federal, state, and local agencies use a coordinated approach for evaluating the planning, regulation, and location of windenergy projects (NRC 2007). The WREZ determined that the rangeland areas of highest wind energy production potential extend from Montana through Wyoming into Colorado, New Mexico, and northern Texas.

Based on the preceding summaries, it is evident that a string of western states from Montana to Texas holds considerable potential for developing biofuels, natural gas, and wind energy sources on rangelands. However, developing one or more of these energy sources requires a comprehensive and integrated 


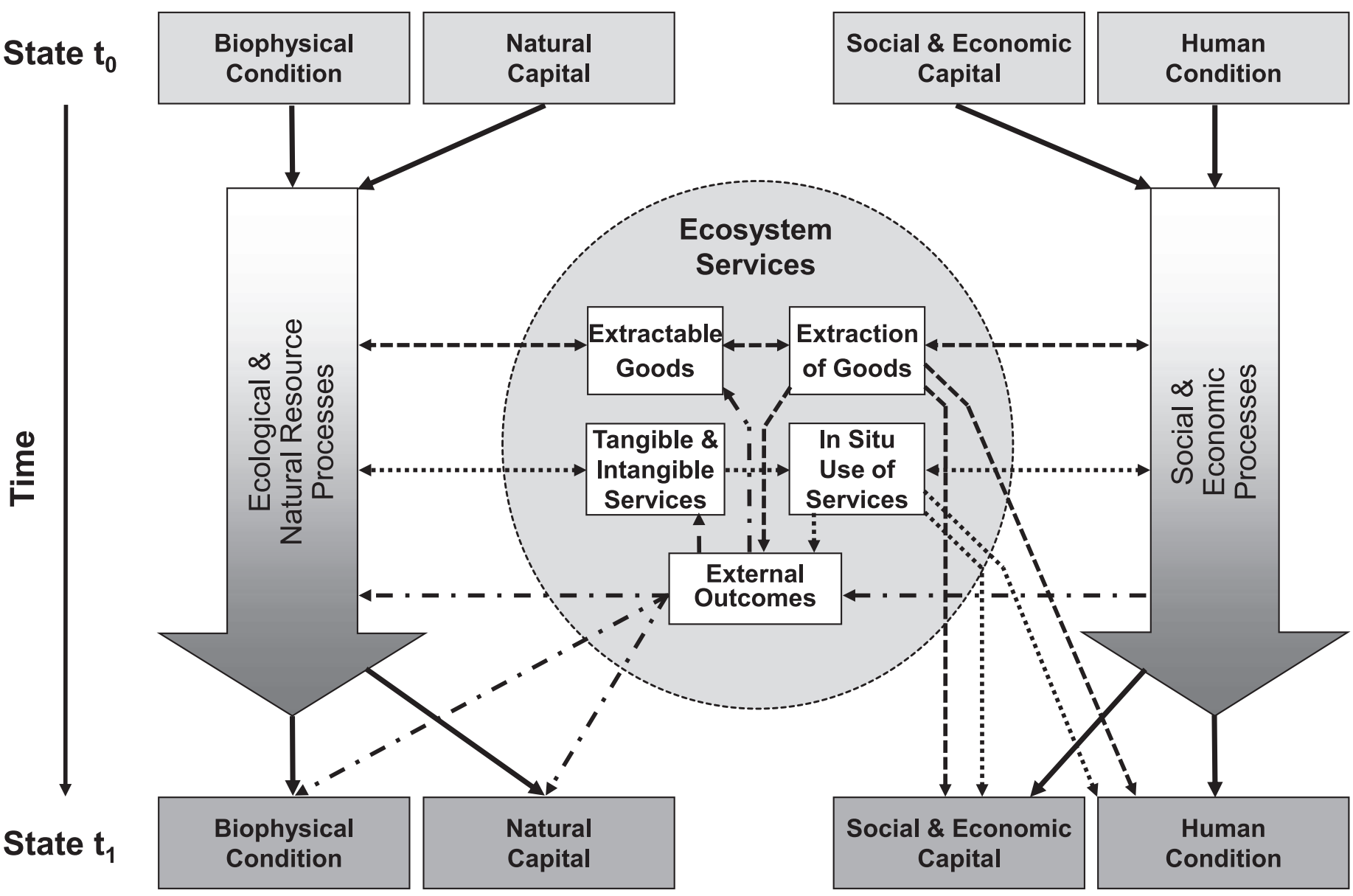

Figure 1. Integrated Social, Economic, and Ecological Concept (ISEEC) for identifying links that affect the delivery of ecosystem goods and services on rangelands (Fox et al. 2009).

assessment to ensure that potential benefits are not outweighed by social and ecological impacts of developing them. This is consistent with the coordinated development approach that was recommended by the NRC's Committee on Environmental Impacts of Wind-Energy Projects. The ISEEC framework has been developed as a user-friendly tool to facilitate such integrated evaluation of social-ecological impacts and coordinate development of rangeland resources, including the sequential or concurrent development of rangeland-based energy sources.

\section{FRAMEWORK FOR LINKING FACTORS AFFECTING ECOSYSTEM SERVICES}

Rangelands comprise socio-ecological systems that provide a broad array of ecosystem goods and services (generically referred to as ecosystem services) that are affected by complex interactions of diverse factors (Maczko and Hidinger 2008). Socio-ecological systems can be represented by two subsystems, the biophysical and the socioeconomic. Inclusion of both these subsystems within a conceptual framework is critical for seeing through the complexity to the underlying structures generating change (Senge 1990).

In the ISEEC framework (Fig. 1), the biophysical characteristics and processes determine the functionality and productiv- ity of rangeland ecosystems and their ability to deliver socially important ecosystem services (Fox et al. 2009). Socioeconomic conditions and processes, on the other hand, create the context in which rangeland ecosystems are used and the way such uses influence the biophysical attributes of the socio-ecological system through time. Ecosystem services, therefore, act as a primary interface between the biophysical and socioeconomic components of socio-ecological systems. In this depiction, the current state of social-ecological systems is categorized into four elements: biophysical condition, natural capital, social and economic capital, and human condition. We use the core concepts of condition and capital to represent the current state and productive capacity, respectively, of the biophysical and socioeconomic elements of the socio-ecological system.

Biophysical condition represents the state of the abiotic and biotic elements of the ecosystem, including air, water, soil, plants, and animals. Natural resource capital represents the stock of all ecosystem elements that lead to productivity including soil structure and fertility, vegetative biomass, and biodiversity. Such natural capital generates flows of ecosystem goods such as biofuel, bio-chemicals, forage, timber and wildlife, as well as ecosystem services, such as water filtration, nutrient cycling, and carbon sequestration. Human condition represents the state of individuals and communities with respect to human well-being, including employment, income 
distribution, health, and security. Social capital is used as an overarching measure of a society's capacity for innovation and adaptation, which is influenced by human capital and civil society (e.g., government institutions and nongovernment organizations that influence human action). Economic capital represents built infrastructure and financial stocks that can generate monetary dividends. Together social and economic capital represents a society's assets or liabilities and opportunities or constraints for human advancement.

The vertical arrows in Figure 1 represent the processes that affect capital and conditions over time. For example, biophysical processes lead to soil genesis, germination, growth and reproduction of plants, plant community shifts, and conversion of plant to animal biomass. Similarly, social and economic processes, such as demographic, cultural, and policy-based factors, influence the socioeconomic characteristics of a society that affect the benefits derived from ecosystem services. These two categories of processes may operate independently or in combination on the states of the biophysical and socioeconomic subsystems existing at the start of the evaluation period $\left(t_{0}\right)$ to produce different states at a later time period $\left(t_{1}\right)$.

Interactions between the biophysical and socioeconomic elements of the socio-ecological system occur through the delivery and utilization of extractable ecosystem goods, in situ delivery and use of ecosystem services, and the negative or positive external effects of human activities, as depicted in the center of Figure 1. Extracted ecosystem goods are used in production of usable commodities that enhance social/economic capital and the human condition. Similarly, ecosystem services can benefit the human condition and social/economic capital through, for example, the provision of soil genesis, clean air and water, biodiversity, and recreational opportunities. The exploitation of ecosystem goods and services can also lead to external negative or positive effects. For example, natural capital and biophysical condition are diminished if ecosystem goods are extracted at rates greater than the capacity of the ecosystem to produce them or through the human impacts resulting from excessive recreational use of aesthetically attractive ecosystems and from waste discharge. By contrast, environmentally-geared social policies can lead to changes in human behavior and investments in ecosystem conservation that enhance natural capital and biophysical condition.

\section{APPLYING ISEEC TO THREE UNCONVENTIONAL ENERGY RESOURCES}

In this section, we first describe the application of the ISEEC framework for a systematic evaluation of potential effects of rangeland-based biofuels development on the socio-ecological links affecting the delivery of goods and services by these ecosystems. Next we demonstrate how the ISEEC framework can be used to systematically compare the effects of developing three unconventional energy sources on rangelands: biofuel, natural gas, and wind energy. Biofuel production was selected for the first of these two steps because broad-scale harvesting of plant biomass for energy production could arguably affect rangeland plant communities in a more fundamental manner than the development of above-ground wind energy or below- ground natural gas. This application of ISEEC is illustrated in Figure 2.

In Figure 2, the biophysical subsystem produces the ecosystem goods and services listed in the center of the diagram. The extent to which these goods and services are utilized is determined by socioeconomic factors shown on the right side of the diagram. Explicitly, [1] and [2] represent the biophysical processes that produce ecosystem goods (e.g., biofuel, forage, and water) and services (e.g., wildlife habitat, water filtration, and aesthetic amenities) on rangelands. Link [3] represents the negative or positive feedback effects on biophysical processes of utilizing or conserving the ecosystem goods and services.

The extraction of rangeland-based ecosystem goods is affected by demand for and supply of biofuel [4] and other rangeland-based goods (water, food, and wildlife) [5]. This is driven by societal demand for energy to produce manufactured goods and services, which is, in turn, affected by population size, wealth, education, cultural norms and values, the legal framework, and other processes affecting human condition and well-being. Investments in technology and management systems needed to meet this demand [8] are not only affected by the level of demand but also by laws, regulations, and incentives that influence investments in alternative markets for ecosystem goods. The deleterious external outcomes (soil erosion, water pollution, green house gas emissions, and biodiversity decline) of using ecosystem goods for energy production [6] are offset by private and public investments in effective mitigation measures [10]. The in situ utilization of ecosystem services (e.g., through recreation) is represented by link [7]. The extent to which these services are utilized is also influenced by social factors affecting demand and investments in the development of industries (e.g., tourism) that facilitate their use [9]. The negative impacts of exploiting such ecosystem services are also moderated by investments in appropriate mitigation measures [10].

To demonstrate the use of the ISEEC framework for comparing the potential effects of developing alternative rangeland-based energy resources, we compare possible effects of developing each of the three unconventional energy resources on each of the 10 links shown in Figure 2. In Table 1 , the biophysical and socio-economic impacts represent the two sides of the benefits and costs ledger for each of the three energy resources. The "+" symbol indicates a positive effect or benefit, "-" indicates a negative effect or cost, and " 0 " indicates no effect. Double symbols represent potentially greater impact of developing the unconventional energy source on the specified link. To be clear, these are anticipated differences and do not represent an assessment of expert opinion or any measured effects, which are lacking. No net effect of developing each energy source is provided in Table 1 because the symbols are not measured effects and, therefore, cannot be summed. In some categories shown in Table 1, this qualitative kind of consideration may be sufficient to indicate an obvious strength or weakness of one alternative or another. In other categories, the advantage or disadvantage might be ambiguous or indeterminate indicating a need for additional, maybe quantitative, analysis.

Biophysical and socioeconomic links identified for biofuel production also apply to natural gas and wind energy 


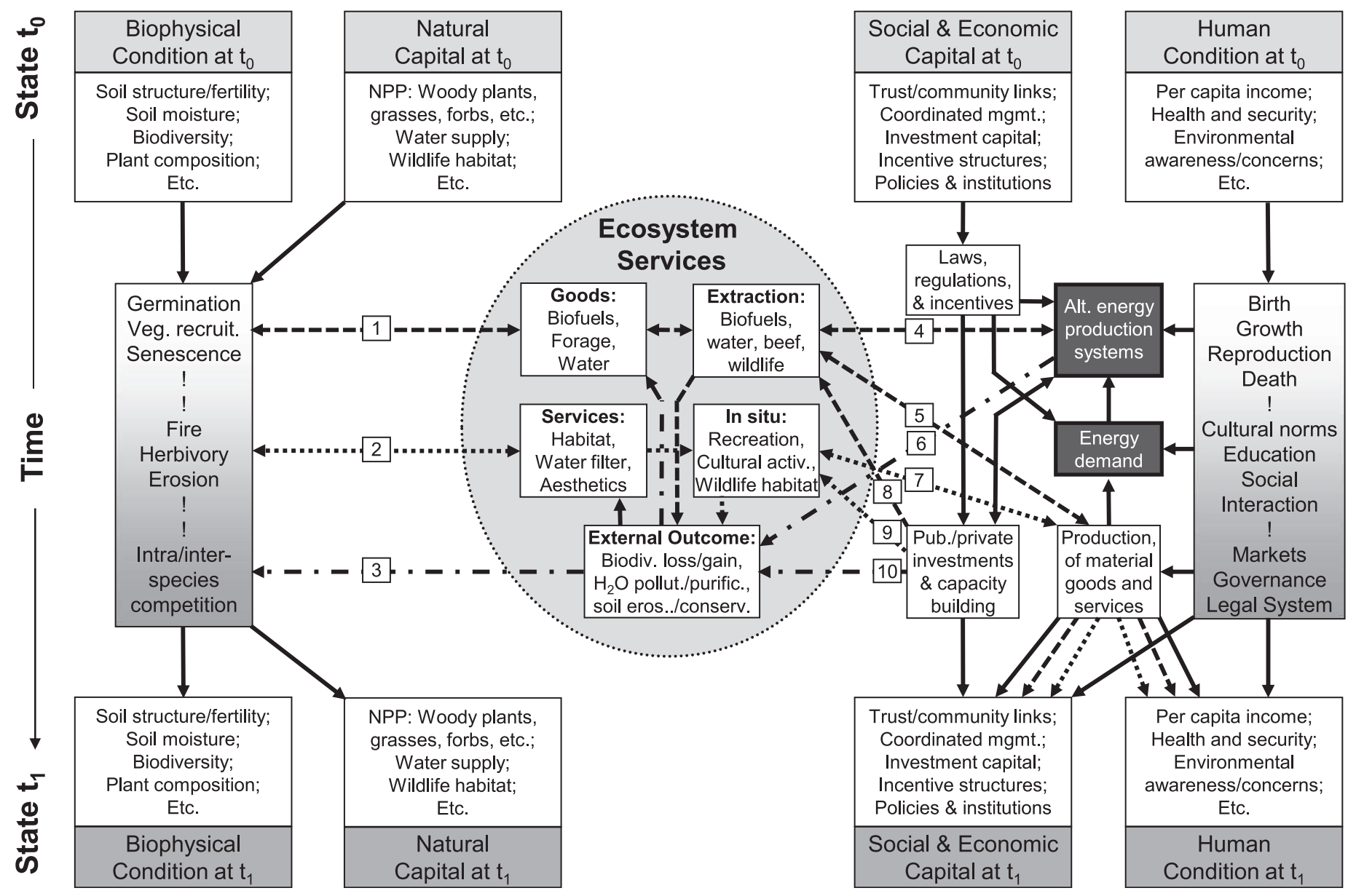

Figure 2. Application of the ISEEC framework to identify key biophysical-socioeconomic links that impact the delivery of ecosystem goods and services, and that affect or are affected by biofuel production from rangeland ecosystems. Numbered boxes indicate links between biophysical and socioeconomic subsystems that affect delivery of ecosystem services and that facilitate comparisons of biofuel, natural gas, and wind energy production in Table 1 and to description of monitoring criteria and indicators in Table 2.

exploitation. On the biophysical side of the ledger, link [1a] refers specifically to the delivery of extractable ecosystem goods for energy production. This benefit is reflected by a double positive symbol in Table 1 . Because natural gas and wind energy are derived from physical resources (shale and wind) located below and above ground level, respectively, they do not rely on rangeland ecosystem resources per se and, therefore, the benefit assigned for them in link [1a] in Table 1 is lower than for biofuels. By contrast, link [1b] refers to the use of ecosystem goods for other purposes, e.g., livestock grazing. The availability of forage may be greater in wind energy and natural gas than biofuel production scenarios because of their lower overall impact on rangeland vegetation compared to the mass harvesting of plant biomass for biofuel. This is reflected in Table 1 by double positive symbols for natural gas and wind energy. There may also be differential impacts on rangeland vegetation from natural gas and wind energy, respectively (not shown in Table 1), because of technological advancements like lateral drilling that may reduce the physical footprint of gas wells.

There may also be differences under the three energy production scenarios with regard to in situ ecosystem services shown in link [2]. The negative effects on biodiversity and allied ecosystem services may be greater from biofuel than natural gas or wind energy if biofuel is harvested uniformly across rangeland landscapes, which may be needed for economic efficiency. Therefore, the amount and quality of in situ ecosystem services in natural gas and wind energy production may be greater than in biofuel production as shown in Table 1.

An analogous argument of asymmetric impacts of developing the three energy types may also apply to the socio-economic link [4]. Because biofuel production depends directly on rangeland plants, whereas wind and natural gas energy production depend on open spaces and underlying natural gas deposits, respectively, it could be argued that the socioeconomic benefits of rangeland ecosystems for biofuel production are greater compared to wind and natural gas energy. These possible differences are reflected in link [4] in Table 1. While the demand for and extraction of ecosystem goods for other purposes (e.g., forage) in link [5] are independent of the type of energy resource, the supply of these other goods may be higher in natural gas and wind energy production due to the potentially lower direct impact on vegetation compared to 
Table 1. Comparative effects on ecosystem (e/s) links shown in Figure 2 for biofuel, natural gas, and wind energy production. ${ }^{1}$

\begin{tabular}{|c|c|c|c|c|c|c|}
\hline \multirow[b]{2}{*}{ Link } & \multicolumn{2}{|c|}{ Biofuel } & \multicolumn{2}{|c|}{ Natural gas } & \multicolumn{2}{|c|}{ Wind } \\
\hline & Bio-phys & Socio-econ & Bio-phys & Socio-econ & Bio-phys & Socio-econ \\
\hline [1a] e/s goods produced: energy & ++ & & 0 & & 0 & \\
\hline [1b] e/s goods produced: other & + & & ++ & & ++ & \\
\hline [2] e/s service supply & + & & ++ & & ++ & \\
\hline$[3]=[6+8+9+10]$ biophysical feedback & -- & & -- & & - & \\
\hline [4] energy supply & & ++ & & + & & + \\
\hline [5] other e/s good supply & & + & & ++ & & ++ \\
\hline [6] direct/indirect energy extraction feedback & & -- & & -- & & - \\
\hline [7] e/s service supply & & 0 & & ++ & & + \\
\hline [8a] e/s extraction investment: energy & & - & & - & & - \\
\hline [8b] e/s extraction investment: other & & - & & - & & - \\
\hline [9] e/s service utilization invest & & - & & - & & - \\
\hline [10] mitigation investments & & -- & & - & & - \\
\hline
\end{tabular}

1 + indicates a positive effect on the link; 0 , no effect; and -, a negative effect. Double symbols reflect a relatively greater effect of developing the energy source on the specified link.

biofuel production. The direct and indirect feedback effects of utilizing ecosystem goods for energy production [6] are discussed below in conjunction with other feedback effects.

The direct benefits of in situ use of ecosystem services shown in link [7] differ among the three forms of energy production. For example, biodiversity may be more impacted by mass harvesting of rangeland plants, which can lead to large-scale habitat destruction, than by the construction of wind generators or natural gas fields where the deleterious effect on biodiversity may be less ubiquitous. Depending on the longevity of biofuel harvesting impact, the aesthetic quality of the affected area may also be compromised. Further, some may consider highly visible wind farms to compromise the recreational quality of an area more than consolidated natural gas pads that may be less obvious from ground level. While such differences are uncertain without thorough testing in numerous locations, based on the previous arguments, the delivery of ecosystem services might be more compromised by biofuel extraction than windmills and natural gas fields (Table 1). The ISEEC framework facilitates systematic postulation of such relationships for subsequent, rigorous testing.

The remaining three socio-economic links reflect investments in the development of new energy resources on rangeland [8], the in situ use of ecosystem services [9], and the legislated or otherwise required mitigation measures to offset the negative effects of developing the new energy resources [10]. These effects may differ among the three energy resources relative to public opinion and private investments, but all three are likely to incur some socioeconomic cost, which is shown to be equivalent for the three energy types in Table 1 . By contrast, the need for investments to mitigate the extraction impacts may vary due to the broad scale effect of biomass extraction relative to the potentially more localized impacts of wind energy and natural gas development (Table 1).

The feedback effects of exploiting ecosystem goods and services for socio-economic benefits on the biophysical functions and processes that produce them are represented by link [3]. These effects are influenced by links [6], [8], [9], and [10]. Specifically, link [6] reflects the direct effects of biomass extraction or the footprint effects of natural gas and wind energy production and also the potential associated indirect effects of greenhouse gas emissions and water extraction. The combustion of energy resources has traditionally produced substantial atmospheric pollutants, which have been identified as a major driver of climate change. However, with emerging energy extraction technologies such emissions are decreasing. It is, therefore, unclear if biofuel and natural gas combustion would result in differential emissions, whereas wind energy extraction produces minimal emissions. An additional potential effect of natural gas extraction is the use of high-pressure hydraulic fracturing (fracking) of the shale formations to release the trapped gas. There is considerable concern that this could pollute ground water, but the effects are unclear and may have limited effects on rangeland ecosystems. Regardless of the relative feedback effects of developing these three energy resources on rangelands, exploiting any of them does not result in zero negative feedback because of associated physical impacts on rangeland plants. These impacts may be greatest for biofuel production due to the mass removal of biomass, while wind turbines and consolidated natural gas well pads, transmission lines, and service roads may result in more limited degradation of vegetation and associated ecosystem services. Due to the potentially greater negative feedbacks (green house gas emissions and water impacts) of biofuel and natural gas than wind energy, development of biofuel and natural gas are assigned double negative signs (link [3]; Table 1).

In addition to feedback effects associated with link [6], the biophysical feedback of developing alterative energy sources [3] is also influenced by the level of investment (effort) in technology for energy extraction [8a] and other purposes, such as livestock grazing [8b], the in situ use of ecosystem services [9], and in mitigation measures implemented to offset negative impacts [10]. From a social perspective, these all incur costs and are, therefore, represented by negative symbols in Table 1 . While many factors can influence these feedback effects (e.g., grazing management goals, rate of development in energy technology, and effectiveness of mitigation measures to offset impacts) and these "costs" may vary among the three energy sources, the differences are 
Table 2. Criteria and indicators for monitoring changes in key links affecting ecosystem goods and services in biofuel, natural gas, and wind energy development on rangelands.

\begin{tabular}{|c|c|c|c|}
\hline Link & Description & Criterion $^{1}$ & Indicator $^{2}$ \\
\hline \multirow[t]{3}{*}{1 and 2} & \multirow{3}{*}{$\begin{array}{l}\text { Composition of plant biomass; Plant } \\
\text { biomass }\end{array}$} & II & Spatial extent of vegetation communities [12] \\
\hline & & & Fragmentation of rangeland plant communities [14] \\
\hline & & III & Above ground plant biomass [21] \\
\hline \multirow[t]{7}{*}{3} & \multirow[t]{3}{*}{ Soil condition } & \multirow[t]{3}{*}{ I } & Area of soils with significantly diminished organic matter and/or C/N ratio [1] \\
\hline & & & Area with significant change in bare ground [4] \\
\hline & & & Area with accelerated soil erosion [5] \\
\hline & \multirow[t]{2}{*}{ Water quality } & \multirow[t]{2}{*}{ I } & Percent surface water with significantly reduced chemical, physical, and biological properties [7] \\
\hline & & & Changes in frequency and duration of surface no-flow periods in streams [9] \\
\hline & \multirow[t]{2}{*}{ Biodiversity } & \multirow[t]{2}{*}{ II } & Spatial extent of vegetation communities [12] \\
\hline & & & Population and range of rangeland-dependent species [20] \\
\hline \multirow[t]{3}{*}{4 and 5} & \multirow{3}{*}{$\begin{array}{l}\text { Biofuel resource utilization; Other } \\
\text { rangeland goods utilization }\end{array}$} & \multirow[t]{3}{*}{ IV } & Value of plants harvested from rangeland [27] \\
\hline & & & Value of production of rangeland products [28] \\
\hline & & & Return on investment in alternative enterprises (livestock, wildlife, water harvesting, biofuel, etc. [32] \\
\hline \multirow[t]{5}{*}{6} & \multirow[t]{5}{*}{ Direct biofuel harvesting impacts } & \multirow[t]{3}{*}{ I } & Area of soils with significantly diminished organic matter and/or C/N ratio [1] \\
\hline & & & Area with significant change in bare ground [4] \\
\hline & & & Area with accelerated soil erosion [5] \\
\hline & & \multirow[t]{2}{*}{$\|$} & Spatial extent of vegetation communities [12] \\
\hline & & & Population and geographic range of rangeland dependent-species [20] \\
\hline \multirow[t]{2}{*}{7} & \multirow[t]{2}{*}{ Rangeland services utilization } & \multirow[t]{2}{*}{ IV } & Return on investment in alternative enterprises (hunting, other recreation, other cultural activities, etc. [32] \\
\hline & & & Area of rangelands under conservation ownership [33] \\
\hline \multirow{6}{*}{$\begin{array}{l}8,9 \text {, and } \\
10\end{array}$} & \multirow{6}{*}{$\begin{array}{l}\text { Public investment and capacity } \\
\text { building; Private investment and } \\
\text { capacity building }\end{array}$} & \multirow[t]{6}{*}{ V } & Extent to which government agencies and NGOs affect conservation/management of rangelands [56] \\
\hline & & & Extent to which economic policies support conservation/management of rangelands [57] \\
\hline & & & Professional education/technical assistance support [59] \\
\hline & & & Conservation/rangeland management support [60] \\
\hline & & & Resources for monitoring rangeland condition [63] \\
\hline & & & Conservation/management research/development support [64] \\
\hline
\end{tabular}

\footnotetext{
${ }^{1}$ Key sustainability criteria identified by Sustainable Rangeland Roundtable (SRR) (Maczko et al. 2004). I, Conservation and maintenance of soil and water resources on rangelands. II, Conservation and maintenance of plant and animal resources on rangelands. III, Maintenance of productive capacity of rangelands. IV, Maintenance and enhancement of multiple economic and social benefits to current and future generations. V, Legal, institutional, and economic frameworks for rangeland conservation and sustainable management.

${ }^{2}$ Indicators for monitoring sustainability of rangeland ecosystems identified by SRR (with brackets providing SRR indicator number; Maczko et al. 2004).
}

uncertain and are therefore all weighted equally in Table 1. As previously stated, while we speculated about the potential effects of energy development on each of the socioeconomicbiophysical links discussed above, the lack of quantitative data prevents us from suggesting an overall net effect of developing these three unconventional energy sources either on their own or in combination. That will require in depth future research. Going through this kind of qualitative exercise, however, provides insight into which elements of an evaluation might permit unambiguous and relatively easy results, and which require more in-depth analyses.

\section{INDICATORS FOR MONITORING BIOPHYSICAL AND SOCIO-ECONOMIC LINKS}

Having established key links affecting the delivery and use of ecosystem services from rangelands with respect to alternative energy sources, the next step is to monitor changes in these links, especially those that are most likely to be differentially affected by the three energy types (as shown in Table 2). This is necessary, because both the biophysical and socioeconomic processes affecting the links are dynamic, resulting in changing biophysical and human conditions as well as natural and socioeconomic capital over time.

From its inception, the discipline of range science has emphasized the need to monitor rangeland resources (Campbell 1948) to identify changes in rangelands, determine trade-offs among alternative rangeland uses, and for rangeland managers to respond effectively to changing conditions. However, indicators used to inventory and monitor rangeland resources focused on biophysical attributes, ignored socioeconomic changes on rangelands, and were not standardized. This makes broad scale comparisons difficult. In recent years, this deficiency led to the establishment by the SRR of five criteria and 64 indicators for monitoring the sustainability of rangelands (Maczko et al. 2004). A criterion is a category of conditions by which the effects of rangeland uses can be systematically assessed relative to sustainable conditions, while indicators measure specific attributes of these criteria that can be periodically quantified to detect change.

SRR criteria and indicators that apply to each of the 10 links shown in Figure 2 were identified in an effort to apply the ISEEC framework to the development of unconventional energy sources on rangelands (Table 2). These can be used to systematically monitor change in the key links over time. The biophysical links [1], [2], and [3] can be monitored by 
indicators that have been commonly used by natural resource scientists and managers, while indicators to monitor the first three socioeconomic links ([4], [5], and [6]) are relatively straightforward and intuitive. More challenging is the identification of indicators that effectively characterize the latter four socio-economic links ([7], [8], [9], and [10]), which relate to the in situ use of ecosystem services and public and private investment in ecosystem goods and services as well as programs aimed at mitigating the deleterious effects of using these goods and services. The reason for this is that many in situ ecosystem services represent public goods from which society at large benefits at the expense of private landowners who provide them without public compensation (Lant et al. 2008). In addition, the values of several ecosystem services (e.g., aesthetic quality) are qualitative, and changes in them are more difficult to evaluate and often require indirect valuation techniques, such as contingent valuation (Daly and Farley 2010).

\section{DISCUSSION}

Developing unconventional energy sources in the United States is critical to meet national energy needs while reducing dependence on foreign oil reserves and to ensure long-term economic sustainability and national security (USDOE 2010). As we have shown, rangelands of the western United States hold considerable promise for natural gas, biofuel, and wind energy production. However, there is considerable debate about the benefits and risks of developing them. Accordingly, those interested in efforts to develop these unconventional energy sources need to comprehensively evaluate in consultation with agencies, landowners, and other stakeholders the impacts of developing them on affected ecosystems, local communities, and economies. Such evaluations need to be science-based and to identify benefits and impacts in the context of current rangeland uses and development plans. Specifically, the environmental (e.g., carbon and water resource), infrastructural, labor, fiscal, and socioeconomic ramifications under various energy development scenarios must be assessed and managed in a manner that does not undermine the ecosystems and communities that support them. Ultimately, this is no easy task due to the complexity and dynamics of rangeland ecosystems as well as the diversity of stakeholder perspectives regarding energy development.

To facilitate disentanglement of such complexity and to integrate feedbacks and interactive effects between the social, economic, and ecological dimensions of rangelands ecosystems, the SRR developed the ISEEC framework as a tool to systematically specify biophysical and socioeconomic links that characterize these social-ecological systems. A key objective of applying the ISEEC framework is to provide consistent and comprehensive information over time to a wide range of decision makers and stakeholders regarding the effects of alternative uses of rangelands on the ecosystem goods and services they provide (Fox et al. 2009). This improves understanding of the effects of rangeland development alternatives on the biophysical attributes of rangelands, on local communities and economies, and on state and federal revenues. Such information is necessary for the formulation of development plans that minimize negative biophysical and socio- economic impacts on complex socio-ecological systems in rangelands.

In this article, we used the ISEEC framework to hypothesize 10 possible biophysical and socio-economic links that influence rangeland-based ecosystem goods and services and may be impacted by development of three unconventional energy resources. We also suggested the direction (benefits and costs) and possible relative magnitudes of the effects related to each energy type on each link. In addition, through the identification of SRR criteria and indicators (Mitchell 2010) to monitor each of these links, we have provided a mechanism for systematically testing the hypothesized effect of each link and to monitor changes in the links over time. In illustrating this use of the ISEEC framework, we did not endeavor to derive bottom-line effects of developing each energy source. Rather we showed how the ISEEC framework can help to unravel complex ecosystems issues and provide consistent terminology in efforts to systematically compare the effects of alterative rangeland uses, specifically energy development, on ecosystem goods and services.

Deriving bottom-line effects of developing alterative energy sources either on their own or in combination requires more detailed evaluation of numerous issues that are beyond the scope of this article. Some issues that need to be addressed include the effects of resource extraction method, methods of energy generation from these resources, and the scale of evaluation. For example, we assumed uniform broad scale harvesting of biofuels. However, the extent to which biofuel harvesting negatively affects biodiversity or net primary production will depend on where and how harvesting occurs; in some cases, harvesting of invasive woody species, such as juniper, may actually increase biodiversity, improve aesthetics, and reduce soil erosion (Scharlemann and Laurance 2008). By contrast, poorly planned wind and natural gas developments can create highly fragmented landscapes and modify predatorprey relationships thereby impacting at-risk species such as sage grouse. In addition to these extraction effects are greenhouse gas emissions during conversion of biofuel and natural gas to electricity, which will depend on the type of conversion technology used. Increasingly, clean energy conversion technologies are leading to lower emissions. Specifications of such effects will be necessary to quantitatively derive net effects of developing each energy source.

Scale of evaluation will also affect the bottom-line assessment. In our illustrative study, we did not specify any spatial scale of analysis; rather we demonstrated, in a general way, how the ISEEC framework can be applied to energy development on rangelands. This approach might be most easily used to evaluate impacts of developing energy resources at the individual property scale because the effects might be more uniform at smaller rather than larger scales. However, due to the large amount of information needed, it may be more likely that the approach would be funded and applied at a regional scale using aggregated information derived through remote sensing of smaller land units. Finally, with some broad assumptions and further aggregation, the approach might also be used to facilitate the derivation of national level estimates of net effects of unconventional energy development on rangelands. 


\section{MANAGEMENT IMPLICATIONS}

Ostrom (2009) emphasized that one problem for planning and management in complex socio-ecological systems is the inconsistent use of concepts and terms, while the NRC (2007) emphasized the need for federal, state, and local agencies to use a coordinated approach for evaluating the planning, regulation, and location of wind-energy projects. These challenges apply to a multitude of rangeland management issues, including the development of unconventional energy resources. Obtaining a conceptual framework to frame and guide an evaluation of energy development on rangelands is the first step to addressing this challenge if the goal of rapidly developing an unconventional fuels industry is to be attained without causing undue environmental and socioeconomic harm. Research to quantify the biophysical-socioeconomic linkages affecting ecosystem goods and services is the next step. Together these will lead to management recommendations to mitigate the potential impacts.

Data to quantitatively compare the effects of developing biofuels, natural gas, and wind energy in rangelands are largely unavailable due to the lack of a consistent conceptual framework guiding the systematic acquisition of such data. The ISEEC framework provides rangeland managers with a tool to systematically and comprehensively identify the biophysical-socioeconomic links that affect the ecosystems they are attempting to manage, to identify suitable indicators for monitoring changes to these links, and to frame and facilitate an evaluation of tradeoffs related to energy development on rangelands. These are the first steps needed to implement energy resource development approaches that minimize the impacts on rangeland ecosystems and to adopt rangeland management practices that mitigate these impacts.

\section{ACKNOWLEDGMENTS}

The authors would like to acknowledge the support of the US Department of the Interior-Bureau of Land Management, the USDA-NRCS, and the USDA Forest Service, which made possible this collaborative project and paper through the Sustainable Rangelands Roundtable.

\section{LITERATURE CITED}

Adler, P. R., S. J. Del Gross, and W. J. Parton. 2007. Life-cycle assessment of net greenhouse-gas flux for bioenergy cropping systems. Ecological Applications 17:675-691.

BIES, L. 2006. The biofuels explosion: is green energy good for wildlife? Wildlife Society Bulletin 34:1203-1206.

Black AND Veatch. 2008. Renewable energy options. Overland Park, KS, USA: Black and Veatch Corporation.

Black and Veatch. 2009. Western renewable energy zones, Phase 1. Overland Park, KS, USA: Black and Veatch Corporation. Project Number 41937.

Bord, J., And S. Banzhaf. 2006. What are ecosystem services? The need for standardized environmental accounting units. Washington, DC, USA: Resources for the Future. RFF DP 06-02. $26 \mathrm{p}$.

CampbelL, R. S. 1948. Milestones in range management. Journal of Range Management 1:4-8.

COOK, J. H., J. BeYEA, AND K. H. KeELER. 1991. Potential impacts of biomass production in the United States on biological diversity. Annual Review of Energy and the Environment 16:401-431.
Curry, A. 2009. Deadly flights. Science 325:386-387.

Daly, H. E., and J. Farley. 2010. Ecological economics: principles and applications. 2nd ed. Washington, DC, USA: Island Press. 509 p.

Dally, G. C., S. Alexander, P. R. Ehrlich, L. Goulder, J. Lubchenco, P. A. Matson, H. A. Mooney, S. Postel, S. H. Schneider, D. Tilman, and G. M. Woodwell. 1997. Ecosystem services: benefits supplied to human societies by natural ecosystems. Issues in Ecology No. 2. Washington, DC, USA: Ecological Society of America. $16 \mathrm{p}$.

DenHoLm, P. 2006. Improving the technical, environmental and social performance of wind energy systems using biomass-based energy storage. Renewable Energy 31:1355-1370.

Duncan, R. C. 2001. World energy production, population growth, and the road to Olduvai gorge. Population and Environment 22:503-522.

EConomides, M. J., And D. A. Wood. 2009. The state of natural gas. Journal of Natural Gas Science and Engineering 1:1-13.

fargione, J., J. Hill, D. Tilman, S. Polasky, and P. Hawthorne. 2008. Land clearing and biofuel carbon debt. Science 319:1235-1237.

Fargione, J. E., T. R. Cooper, D. J. Flaspohler, J. Hill, C. Lehman, T. McCoy, S. McLeod, E. J. Nelson, K. S. Oberhauser, and D. Tilman. 2009. Bioenergy and wildlife: threats and opportunities for grassland conservation. Bioscience 59:767-777.

Fox, W. E., D. W. McCollum, J. E. Mitchell, J. A. Tanaka, U. P. Kreuter, L. E. Swanson, G. R. Evans, H. T. Heintz, R. P. Breckenridge, and P. H. Geissler. 2009. An integrated social, economic, and ecologic conceptual (ISEEC) framework for considering rangeland sustainability. Society and Natural Resources 22:593-606.

Gasparatos, A., P. Stromberg, and K. Takeuch. 2011. Biofuels, ecosystem services and human wellbeing: putting biofuels in the ecosystem services narrative. Agriculture, Ecosystems and Environment 142:111-128.

Groom, M. J., E. M. Gray, and P. A. Townsend. 2008. Biofuels and biodiversity: principles for creating better policies for biofuel production. Conservation Biology 22:602-609.

[GWPaC] Groundwater Protection Council and AlL Consulting. 2009. Modern shale gas development in the United States: a primer. Washington, DC, USA: US Department of Energy, Fossil Energy \& National Energy Technology Laboratory. Award DE-G26-04NT15455. $98 \mathrm{p}$.

Havstad, K. M., D. P. C. Peters, R. Skaggs, J. Brown, B. Bestelmeyer, E. Fredrickson, J. HerRick, And J. Wright. 2007. Ecological services to and from rangelands of the United States. Ecological Economics 64:261-268.

Holechek, J. L., R. D. Pieper, And C. H. Herbel. 2004. Range management: principles and practices. 5th ed. Upper Saddle River, NJ, USA: Pearson and Prentice Hall. $607 \mathrm{p}$.

JoYCE, L. A. 1989. An analysis of the range forage situation in the United States: 1989-2040. Washington, DC, USA: US Forest Service Rocky Mountain Research Station. General Technical Report RM-180. 137 p.

Kalogirou, S. 2005. Seawater desalination using renewable energy sources. Progress in Energy and Combustion Science 31:242-281.

Krohn, S., AND S. Damborg. 1999. On public attitudes towards wind power. Renewable Energy 16:954-960.

Kucera, C. L., R. C. Dahlman, and M. R. Koelung. 1967. Total net productivity and turnover on an energy basis for tallgrass prairie. Ecology 48:536-541.

Kunz, T. H., E. B. Arnett, W. P. Erickson, A. R. Hoar, G. D. Johnson, R. P. Larkin, M. D. Strickland, R. W. Thresher, and M. D. Tuttle. 2007. Ecological impacts of wind energy development on bats: questions, research needs, and hypotheses. Frontiers in Ecology and the Environment 5:315-324.

KuuskraA, V. A., M. L. Godec, and S. R. ReEves. 2007. Outlook for unconventional gas: the next decade. OGJ Unconventional Gas Article \#6. Houston, TX, USA: Advanced Resources International. $14 \mathrm{p}$.

Lant, C., J. B. Ruhl, and S. E. Kraft. 2008. The tragedy of ecosystem services. BioScience 58:969-974.

Maczko, K. A., L. D. Bryant, D. W. Thompson, and S. J. Borchard. 2004. Putting the pieces together: assessing social, ecological, and economic rangeland sustainability. Rangelands 26:3-14.

MaczKo, K., AND L. Hidinger [eds.]. 2008. Sustainable rangelands: ecosystem goods and services. Sustainable Rangelands Roundtable, Colorado State University. Available at: http://sustainable.rangelands.org/pdf/Ecosystem_Goods_Services. pdf. Accessed 20 February 2012. 
Millennium Ecosystem Assessment. 2005. Ecosystems and human well-being: synthesis. Washington, DC, USA: Island Press. 137 p.

MitcheLL, J. E. 2000. Rangeland resource trends in the United States. Washington, DC, USA: US Forest Service Rocky Mountain Research Station. Genera Technical Report RMRS-GTR-68. 84 p.

MitchelL, J. E. [ED.]. 2010. Criteria and indicators of sustainable rangeland management. Laramie, WY, USA: University of Wyoming Extension. Publication No. SM-56. 227 p. Available at: http://www.sustainablerangelands.org/pdf/ SM56.pdf. Accessed 12 February 2012.

Mitchell, R. B., K. P. Vogel, and G. Sarath. 2008. Managing and enhancing switchgrass as a bioenergy feedstock. Biofuels, Bioproducts and Biorefining 2:530-539.

[NRC] National Research Council. 2007. Environmental impacts of wind-energy projects. Committee on Environmental Impacts of Wind-Energy Projects, Board on Environmental Studies and Toxicology, Division on Earth and Life Studies, National Research Council of the National Academies. Washington, DC, USA: The National Academies Press. $394 \mathrm{p}$.

Nicholson, E., G. M. Mace, P. R. Armsworth, G. Atrinson, S. Buckle, T. Clements, R. M. Ewers, J. E. Fa, T. A. Gardner, J. Gibbons, R. Grenyer, R. Metcalfe, S. Mourato, M. Muúls, D. Osborn, D. C. Reuman, C. Watson, and E. J. Mllner-Gulland. 2009. Priority research for ecosystem services in a changing world. Journal of Applied Ecology 46:1139-1144.

OsтRom, E. 2009. A general framework for analyzing sustainability of social-ecological systems. Science 325:419-422.

Pimentel, D., G. Rodrigues, T. Wang, R. Abrams, K. Goldberg, H. Staecker, E. Ma, L. Brueckner, L. Trovato, C. Chow, U. Govindarajulu, and S. Boerke. 1994. Renewable energy: economic and environmental issues. BioScience 44:536-547.

Scharlemann, J. P., and W. F. Laurance. 2008. How green are biofuels? Science 319:43-44.

SengE, P. 1990. The fifth discipline: the art and practice of the learning organization. New York, NY, USA: Doubleday. 445 p.
Serageldin, I. 1999. Biotechnology and food security in the 21st century. Science $285: 387-389$

SMLL, V. 2000. Energy in the twentieth century: resources, conversions, costs, uses, and consequences. Annual Review of Energy and the Environment 25:21-51.

Society for Range Management. 1998. Glossary of terms used in range management. 4th ed. Denver, C0, USA: Society for Range Management. $32 \mathrm{p}$.

Stoddardt., L. A., T. W. Box, and A. D. Smith. 1975. Range Management. New York, NY, USA: McGraw Hill. 532 p.

TiLman, D., J. HILL, And C. Lehman. 2006. Carbon-negative biofuels from low-input highdiversity grassland biomass. Science 314:1598-1600.

[USDOE] US Department of Energy. 2005. Biomass as feedstock for a bioenergy and bioproducts industry: the technical feasibility of a billion-ton annual supply. Oak Ridge, TN, USA: Office of Science and Technical Information. Available at: www1.eere.energy.gov/biomass/pdfs/final_billionton_vision_report2.pdf. Accessed 20 February 2012.

USDOE. 2006. US crude oil, natural gas, and natural gas liquids reserves 2005 Annual Report. Washington, DC, USA: USDOE. Report no. DOE/EIA-0216. 48 p.

USDOE. 2010. US petroleum reserves. Available at: http://fossil.energy.gov/ programs/reserves/. Accessed 20 February 2012.

Walsh, M. E., H. D. G. De La Torre Ugarte, S. Shapouri, and P. Slinsky. 2003. Bioenergy crop production in the United States. Environmental and Resource Economics 24:313-333.

Western Governors' Association. 2009. Finding the right path on energy and climate change. 2009 Annual Report. Denver, C0, USA: Western Governors' Association. Available at: http://www.westgov.org/component/joomdoc/doc_details/ 98-wga-annual-report-2009. Accessed 20 February 2012.

World Resources Institute. 1986. World Resources 1986: an assessment of the resource base that supports the global economy. New York, NY, USA: Basic Books. 348 p. 